\title{
Perancangan Sistem Pendukung Keputusan Seleksi Asisten Dosen Menggunakan Kombinasi Metode Profile Matching dan TOPSIS Berbasis Web Service
}

\author{
Ramos Somya $^{1 *}$, Retantyo Wardoyo ${ }^{2}$ \\ ${ }^{1}$ Program Studi S1 Teknik Informatika, Fakultas Teknologi Informasi \\ Universitas Kristen Satya Wacana \\ Salatiga, Jawa Tengah \\ ${ }^{2}$ Departemen Ilmu Komputer dan Elektronika \\ Universitas Gadjah Mada \\ Yogyakarta \\ *ramos.somya@uksw.edu
}

\begin{abstract}
Abstrak-Seleksi asisten dosen di Fakultas Teknologi Informasi Universitas Kristen Satya Wacana (FTI UKSW) dilakukan setiap awal semester. Proses seleksi tersebut mengalami beberapa kendala, antara lain mahasiswa harus datang langsung ke kantor tata usaha untuk melakukan pendaftaran yang ditulis di form pendaftaran. Form pendaftaran juga pernah hilang sehingga harus dilakukan pendaftaran ulang. Proses seleksi dilakukan oleh koordinator dosen mata kuliah dengan mengadakan tes atau wawancara untuk mencari beberapa informasi untuk dijadikan pertimbangan dalam memilih asisten dosen. Proses seleksi memakan waktu yang lama, sehingga menyebabkan kegiatan praktikum menjadi terlambat untuk dimulai. Pada penelitian ini dibuat pemodelan Sistem Pendukung Keputusan (SPK) menggunakan metode TOPSIS dan Profile Matching berbasis teknologi Web Service untuk mengatasi masalah dalam proses pendaftaran dan seleksi asisten dosen di FTI UKSW. Hasil akhir perhitungan menggunakan metode TOPSIS dan Profile Matching ini berbentuk ranking yang dapat digunakan untuk membantu dosen koordinator mata kuliah dalam menentukan calon asisten dosen yang akan diterima.
\end{abstract}

Kata kunci: asisten dosen, profile matching, sistem pendukung keputusan, topsis, web service

\section{Pendahuluan}

Dosen merupakan faktor utama dalam sebuah proses perkuliahan karena dosen berinteraksi langsung dengan mahasiswa. Pada beberapa mata kuliah juga dibutuhkan asisten dosen yang diharapkan dapat membantu dosen dalam proses perkuliahan. Asisten dosen adalah orang-orang yang diangkat sebagai tenaga pengajar untuk membantu tugas-tugas dosen yang akan mendapat bimbingan dosen tersebut lebih lanjut. Dalam melaksanakan fungsinya dalam pengelolaan perkuliahan, maka dosen dan asisten dosen melaksanakannya secara bersama-sama, mulai dari perencanaan perkuliahan, pelaksanaan perkuliahan sampai dengan penilaian hasil belajar mahasiswa [1].

Fakultas Teknologi Informasi Universitas Kristen Satya Wacana (FTI UKSW) merupakan fakultas yang memiliki banyak mata kuliah yang membutuhkan asisten dosen. Asisten dosen ini bertugas mengajar di kelas praktikum maupun mendampingi dan membantu dosen dalam mengajar di kelas atau di laboratorium. Untuk mendaftar sebagai asisten dosen mata kuliah, dibutuhkan nilai minimal mata kuliah tersebut yaitu $\mathrm{B}$ dan Indeks Prestasi Kumulatif (IPK) minimal 2.75 . Selain itu, dibutuhkan pula pengalaman pernah menjadi asisten dosen sebelumnya, frequent pengalaman asisten dosen sebelumnya, batasan banyaknya mata kuliah yang didaftarkan sebagai asisten dosen, dan nilai tes seleksi.

Proses pendaftaran asisten dosen di FTI UKSW dilakukan dengan cara mendaftar di kantor tata usaha yaitu dengan mengisi form pendaftaran asisten dosen kemudian oleh dosen koordinator mata kuliah akan diadakan seleksi. Seleksi asisten dosen ini dilakukan dengan cara wawancara maupun tes. Proses pendaftaran asisten dosen di kantor tata usaha tersebut mengalami beberapa kendala. Mahasiswa yang ingin mendaftar sebagai asisten dosen harus datang langsung ke tata usaha untuk mengisi form pendaftaran dan sering kali harus mengantri terlebih dahulu. Form pendaftaran yang masih berupa kertas juga pernah hilang sehingga data pendaftar asisten dosen suatu mata kuliah juga hilang. Hal ini mengakibatkan dosen koordinator mata kuliah tidak bisa melakukan proses seleksi dengan cepat.

Setelah melewati tahap pendaftaran asisten dosen, para pendaftar biasanya harus mengikuti tahap seleksi, yaitu melalui wawancara maupun tes. Pada proses wawancara akan ditanyakan beberapa hal untuk dijadikan pertimbangan dalam memilih asisten dosen. Hal ini memakan waktu yang lama apalagi jika harus dilakukan tes. Lamanya proses seleksi ini menimbulkan terlambatnya kegiatan praktikum karena saat praktikum atau kuliah sudah dimulai, belum mendapatkan asisten dosen. 
Terdapat beberapa penelitian terdahulu yang membahas tentang seleksi asisten dosen dan penentuan karyawan terbaik dengan teknik perangkingan. Penelitian [2] membahas tentang analisis dan perancangan sistem pendaftaran dan ujian seleksi asisten dosen di STMIK STIKOM Bali. Perancangan sistem tersebut menggunakan diagram Unified Modelling Language (UML). Hasil penelitian tersebut adalah sebuah desain perangkat lunak yang dapat diimplementasikan menjadi software yang utuh.

Penelitian [3] membahas tentang sistem pendukung keputusan seleksi asisten laboratorium dosen elektro menggunakan metode Weighted Product. Pada penelitian ini, setiap inputan nilai kriteria dari masing-masing calon pelamar akan dilakukan perbandingan guna memperoleh nilai bobot. Hasil dari nilai bobot akan dilakukan penilaian untuk mencari rangking calon pelamar yang akan dipilih menjadi tenaga asisten dosen.

Penelitian [4] membahas tentang penentuan karyawan terbaik menggunakan metode TOPSIS dan Borda. Metode TOPSIS digunakan untuk pengambilan keputusan di setiap penilai, sedangkan metode Borda digunakan untuk menggabungkan hasil keputusan dari tiap penilai sehingga memperoleh hasil akhir berupa karyawan terbaik di hotel Lombok Garden.

Pada penelitian ini akan dibuat pemodelan sistem pendaftaran dan seleksi asisten dosen berbasis web menggunakan metode TOPSIS dan Profile Matching dengan memanfaatkan teknologi Web Service. Keterbaharuan pada penelitian ini adalah pada kombinasi penggunaan metode Profile Matching dan TOPSIS. Profile Matching berguna untuk menangani parameter yang bukan didasarkan pada nilai maksimum (benefit) dan minimum (cost) seperti yang berlaku pada metode perangkingan Multi Criteria Decision Making (MCDM), tetapi berupa nilai ideal yang harus dipenuhi sesuai dengan persyaratan pengambil keputusan. Pada kasus seleksi asisten dosen ini terdapat 2 kriteria (parameter) yang didasarkan pada nilai ideal yang ditentukan oleh pengambil keputusan. Kedua kriteria tersebut akan diproses dengan metode Profile Matching dan hasilnya akan diproses lebih lanjut dengan metode TOPSIS untuk mendapatkan hasil akhir berupa rangking.

Pemilihan asisten dosen di FTI UKSW didasarkan pada 5 kriteria, yaitu: Indeks Prestasi Kumulatif (IPK), nilai mata kuliah yang ingin didaftarkan untuk menjadi asisten dosen, nilai tes seleksi, jumlah pengalaman asisten dosen sebelumnya, dan jumlah mata kuliah yang didaftarkan untuk menjadi asisten dosen. Pada penelitian ini, metode TOPSIS akan dikombinasikan dengan metode Profile Matching. Metode Profile Matching di sini akan digunakan untuk memproses kriteria yang didasarkan pada preferensi pengambil keputusan.

Pada proses pemilihan asisten dosen, pengambil keputusan yaitu dosen koordinator mata kuliah mensyaratkan nilai dari kriteria jumlah asisten dosen sebelumnya adalah sekitar 2 kali dan jumlah mata kuliah yang didaftarkan untuk menjadi asisten dosen pada periode pendaftaran adalah sekitar 3 mata kuliah. Hasil pemrosesan dengan Profile Matching akan digabungkan dengan kriteria lainnya pada metode TOPSIS. Pada penelitian ini juga digunakan teknologi Web Service untuk melakukan seleksi awal dalam pemilihan asisten dosen. Web Service akan melakukan pengecekan nilai mata kuliah dan
IPK calon asisten dosen di Sistem Informasi Akademik Satya Wacana (SIASAT) sebagai syarat awal pendaftaran asisten dosen. Jika syarat IPK dan nilai mata kuliah sesuai dengan ketentuan, maka proses akan dilanjutkan ke tahap perangkingan dengan metode TOPSIS dan Profile Matching.

\section{Tinjauan Pustaka}

\section{a. Sistem Pendukung Keputusan}

Sistem Pendukung Keputusan (SPK) digunakan sebagai alat bantu bagi para pengambil keputusan untuk memperluas kapabilitas para pengambil keputusan, tetapi tidak untuk menggantikan penilaian para pengambil keputusan. SPK ditujukan untuk keputusan yang memerlukan penilaian atau untuk keputusan-keputusan yang sama sekali tidak dapat didukung oleh algoritma. SPK meluas dengan cepat, dari sekadar alat pendukung personal menjadi komoditas yang dipakai bersama [5]. Tahapan proses pengambilan keputusan terdiri dari beberapa langkah, yaitu: (a) Tahap Penelusuran (Intelligence), (b) Tahap Perancangan (Design), (c) Tahap Pemilihan (Choice), dan (d) Tahap Implementasi (Implementation).

\section{b. Multi Criteria Decision Making (MCDM)}

Multi-criteria Decision Making Methods dapat diklasifikasikan menjadi 3 kelompok. Kelompok pertama disebut dengan Partial Aggregation Approach, terdiri dari perbandingan berbagai kemungkinan keputusan per pasangan. Jenis yang kedua disebut dengan Complete Aggregation Approaches, di mana dalam pendekatan ini akan menggabungkan semua kriteria dalam unity function untuk kemudian dipakai dalam pembuatan keputusan. Jenis ketiga adalah Highly Interactive, di mana akan dirancang keputusan awal dan membandingkannya dengan keputusan lain yang terkait untuk menentukan yang terbaik [6], [7].

Tujuan utama dari metode yang dikembangkan ini adalah untuk membantu pengambil keputusan memecahkan masalah yang kompleks mengenai kriteria yang biasanya saling bertentangan dan kualitatif. Ide yang mendasari di balik MCDM telah diimplementasikan di berbagai bidang untuk memecahkan berbagai masalah seperti pemilihan, pemilahan, dan perangkingan [8].

\section{c. Metode TOPSIS}

Metode TOPSIS merupakan salah satu metode dalam MCDM. Metode TOPSIS didasarkan pada konsep di mana alternatif terpilih yang terbaik tidak hanya memiliki jarak terpendek dari solusi ideal positif, tetapi juga memiliki jarak terpanjang dari solusi ideal negatif [9]. TOPSIS digunakan karena beberapa alasan, yaitu: konsepnya sederhana dan mudah dipahami, komputasinya efisien, dan memiliki kemampuan untuk mengukur kinerja relatif dari alternatif-alternatif keputusan dalam bentuk matematis yang sederhana. Secara umum, langkah-langkah dalam metode TOPSIS adalah: 1) Membuat matriks keputusan yang ternormalisasi; 2) Mambuat matriks keputusan yang ternormalisasi terbobot; 3) Menentukan matriks solusi ideal positif dan matriks solusi ideal negatif; 4) Menentukan jarak antara nilai setiap alternatif dengan matriks solusi ideal positif dan matriks solusi ideal negatif; 5) Menentukan nilai preferensi untuk setiap alternatif. 


\section{d. Metode Profile Matching}

Profile Matching merupakan sebuah mekanisme scoring dalam pengambilan keputusan dengan mengasumsikan bahwa terdapat tingkat variabel prediktor yang ideal yang harus dipenuhi oleh subjek yang diteliti, bukannya maksimum atau minimum [10]. Profile Matching merupakan salah satu metode scoring data. Penentuan scoring bisa dengan referensi langsung dengan target atau melalui perhitungan gap (selisih antara data dengan target).

\section{e. Web Service}

Web Service adalah aplikasi perangkat lunak yang dapat diakses dari jarak jauh menggunakan bahasa berbeda berbasis XML (eXtensible Markup Language) [11]. Teknologi Web Services menawarkan kemudahan dalam menjembatani sumber-sumber informasi tanpa mempermasalahkan perbedaan teknologi yang digunakan di tiap sumber. Misalkan sebuah situs informasi dibangun dengan menggunakan database Oracle sedangkan situs lainnya menggunakan MySQL, maka aplikasi Web Services akan mengatasi perbedaan ini. Web Services diperlukan karena pada masa sekarang ini perangkat keras, sistem operasi, aplikasi hingga bahasa pemrograman semakin beraneka ragam jenisnya.

\section{Metode}

\section{a. Proses Bisnis}

Terdapat dua prosedur pendaftaran yang akan dijelaskan, yaitu pendaftaran yang masih manual dan pendaftaran dengan menggunakan sistem yang telah dibuat. Pendaftaran dengan cara manual adalah sebagai berikut: 1) Mahasiswa datang terlebih dahulu ke bagian kantor tata usaha di fakultas; 2) Mengisi form pendaftaran yang telah disediakan; 3) Memilih mata kuliah praktikum asisten yang akan diambil dan mengisi ketentuan apa saja yang diperlukan untuk mendaftar satu per satu; 4) Mahasiswa harus memastikan sendiri, apakah sudah mengambil mata kuliah tersebut atau nilai yang ditentukan sudah mencukupi untuk melakukan pendaftaran ataukah belum.

Pendaftaran mengunakan sistem yang akan dimodelkan adalah sebagai berikut: 1) Mahasiswa tidak perlu datang langsung ke kantor tata usaha karena pendaftaran dilakukan secara online; 2) Mahasiswa melakukan login dengan nomor induk dan kata sandi yang telah dimiliki; 3) Mahasiswa yang sudah melakukan login akan masuk di halaman utama website yang memiliki menu registrasi, kartu asisten dosen, dan berita mengenai sistem pendaftaran; 4) Mahasiswa dapat melakukan registrasi pendaftaran sesuai dengan kelas mata kuliah yang dibuka pada semester itu; 5) Sistem akan mengecek terlebih dahulu apakah mahasiswa dengan nomor induk tersebut sudah mencukupi untuk melakukan pendaftaran ataukah belum (IPK dan nilai mata kuliah minimum); 6) Apabila mahasiswa tersebut belum tuntas atau belum memenuhi persyaratan, maka akan muncul peringatan dan mahasiswa tersebut tidak dapat melakukan pendaftaran.

\section{b. Kebutuhan Input, Kriteria, dan Output}

Sistem Pendukung Keputusan seleksi asisten dosen ini mempunyai inputan awal berupa Nomor Induk Mahasiswa (NIM) dan password yang diinputkan saat melakukan login ke sistem untuk mendaftar menjadi asisten dosen. Kemudian mahasiswa mendaftarkan diri dengan memilih mata kuliah yang dibuka untuk kelas praktikum maupun asistensi. Sistem akan memeriksa nilai mata kuliah dan IPK mahasiswa tersebut apakah sesuai dengan syarat atau tidak. Teknologi Web Service digunakan untuk melakukan pemeriksaan nilai dan IPK minimal ini, yaitu dengan memeriksa transkip nilai mahasiswa tersebut dalam basis data. Sistem Informasi Akademik Satya Wacana (SIASAT). Untuk mendaftar sebagai asisten dosen mata kuliah dibutuhkan nilai minimal mata kuliah tersebut yaitu B dan IPK minimal 2.75. Jika nilai dan IPK minimal tidak memenuhi syarat, maka pendaftaran akan ditolak. Jika nilai dan IPK minimal memenuhi syarat, maka akan dilanjutkan ke proses seleksi selanjutnya dengan memperhitungkan kriteria lainnya yaitu: nilai tes seleksi, jumlah pengalaman asisten dosen sebelumnya dan jumlah mata kuliah yang didaftarkan untuk menjadi asisten dosen. Sistem ini akan menghasilkan output berupa daftar asisten dosen dalam bentuk perangkingan dengan metode TOPSIS dan Profile Matching dari rangking pertama hingga terakhir. Dosen koordinator mata kuliah selanjutnya hanya perlu memilih asisten dosen berdasarkan rangking tersebut dan dapat menyimpannya dalam format Excel untuk kemudian dilakukan proses pembagian kelas mengajar. Arsitektur sistem secara keseluruhan ditunjukkan pada Gambar 1.

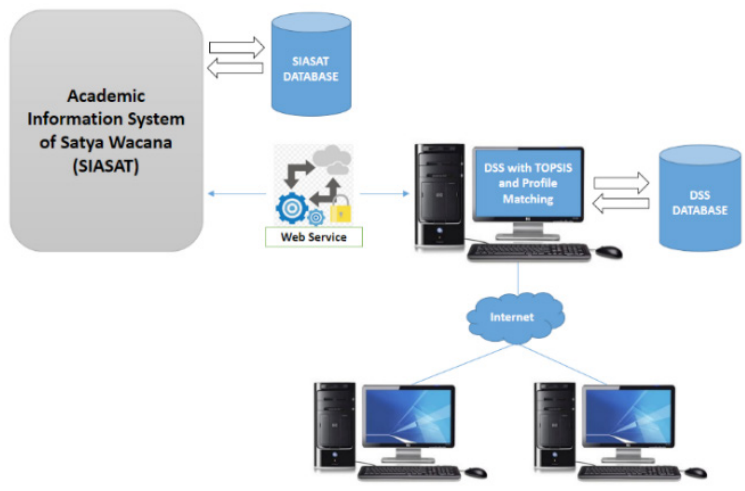

Gambar 1. Arsitektur SPK seleksi asisten dosen

\section{c. Perancangan Sistem}

Perancangan sistem pada penelitian ini dilakukan menggunakan UML (Unified Modeling Language) yaitu digambarkan dengan Use Case Diagram dan Class Diagram. Diagram tersebut dapat dilihat pada Gambar 2 dan Gambar 3. Use Case Diagram merupakan salah satu diagram UML yang digunakan untuk mendefinisikan fungsionalitas sistem dengan menggambarkan aktor, use case, dan relasinya [12]. Use case diagram berfungsi juga untuk menggambarkan kebutuhan pengguna sistem. [13]. Sedangkan Class Diagram dapat digunakan untuk menggambarkan konseptual skema dari sebuah sistem [14].

Gambar 2 menunjukkan Use Case Diagram masingmasing aktor, yaitu: mahasiswa, dosen koordinator mata kuliah, dan admin SPK. Aktor mahasiswa dapat melakukan registrasi pendaftaran, melihat kartu asisten dan peserta pendaftar lainnya. Aktor dosen koordinator mata kuliah dapat melihat daftar mahasiswa yang mendaftar asisten dosen, melakukan penyeleksian asisten dosen, pengaturan asisten dosen dan kelas praktikum. Aktor admin SPK 
dapat melakukan pengaturan mata kuliah seperti melihat, menambah, hapus, dan ubah mata kuliah, juga dapat melakukan pengaturan koordinator dosen.

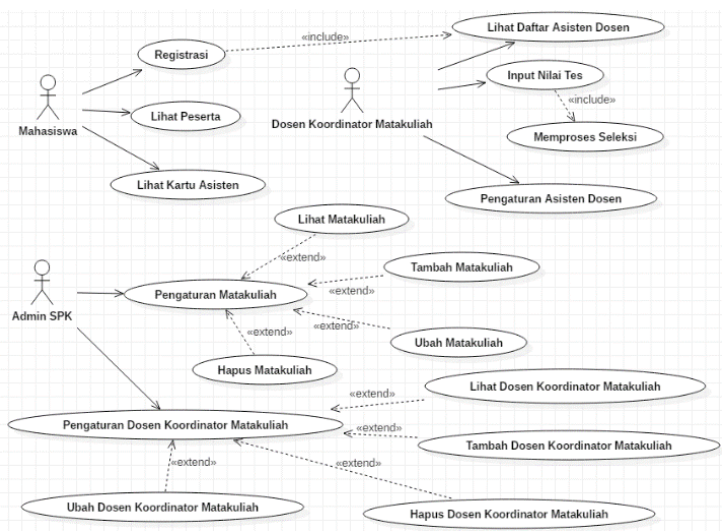

Gambar 2. Use case diagram sistem

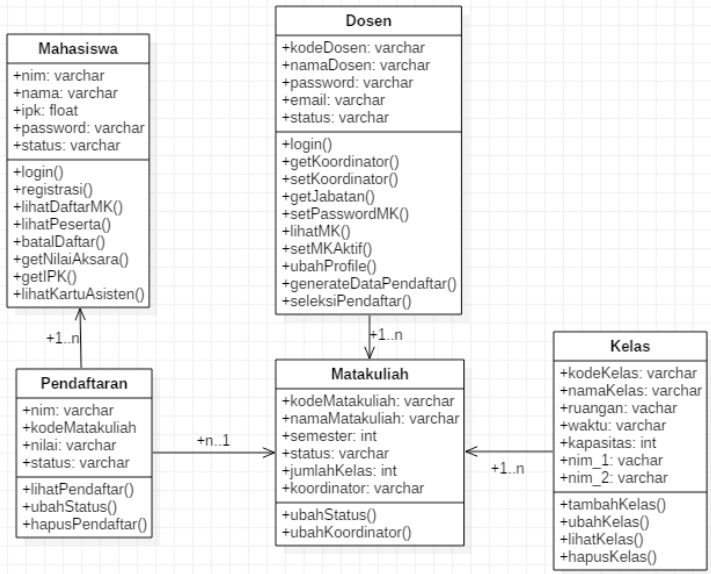

Gambar 3. Class diagram sistem

Gambar 3 menunjukkan Class Diagram sistem yang terdapat pada rancangan aplikasi sistem pendaftaran dan seleksi asisten dosen. Relasi yang terjadi antara kelas Mahasiswa dan Pendaftaran adalah one to many, di mana 1 mahasiswa dapat mendaftar lebih dari 1 mata kuliah. Relasi antara kelas Mata Kuliah dan Pendaftaran adalah one to many, di mana 1 mata kuliah terdiri dari banyak pendaftar. Relasi antara kelas Mata Kuliah dan Kelas adalah one to many, di mana 1 mata kuliah terdiri dari beberapa kelas. Sedangkan relasi antara kelas Dosen dan Mata Kuliah adalah one to many, di mana seorang dosen dapat menjadi koordinator lebih dari 1 mata kuliah.

\section{Hasil}

Hasil dan pembahasan ini akan menjelaskan tentang proses seleksi awal pada saat pendaftaran asisten dosen, dimana sistem akan melakukan pengecekan untuk nilai mata kuliah dan IPK yang ada di basis data SIASAT. Proses pengecekan ini dilakukan dengan Web Service, dan akan mengembalikan hasil apakah mahasiswa pendaftar memenuhi syarat minimum atau tidak. Penjelasan berikutnya adalah proses perhitungan perangkingan asisten dosen dengan metode TOPSIS dan Profile Matching. Gambar 4 merupakan tampilan aplikasi yang menunjukkan daftar mata kuliah yang dibuka pendaftaran untuk seleksi asisten dosen.

Daftar Matakuliah Praktikum (Semester Genap 2018/2019)

\begin{tabular}{|l|l|c|l|c|}
\hline Kode Matakuliah & \multicolumn{1}{|c|}{ Nama Matakuliah } & Jumlah Pendaftar & Peserta & Daftar \\
\hline IN123 & Pemrograman & 10 & LIHAT PESERTA & DAFTAR \\
\hline IN157 & Algoritma dan Struktur Data & 25 & LIHAT PESERTA & DAFTAR \\
\hline IN165 & Sistem Operasi & 34 & LIHAT PESERTA & DAFTAR \\
\hline IN168 & Pengantar Teknologi Informasi & 55 & LIHAT PESERTA & DAFTAR \\
\hline IN221 & Pemrograman Berorientasi Platform & 28 & LIHAT PESERTA & DAFTAR \\
\hline
\end{tabular}

Gambar 4. Tampilan pada aplikasi untuk daftar mata kuliah praktikum

Berdasarkan Gambar 4, calon asisten dosen dapat memilih tautan DAFTAR untuk mendaftar menjadi asisten dosen mata kuliah tertentu. Pada proses daftar ini, sistem akan melakukan pengecekan data pada basis data SIASAT untuk mengetahui apakah pendaftar memenuhi syarat minimum nilai mata kuliah dan IPK. Gambar 5 merupakan tampilan aplikasi untuk hasil pengecekan awal ini jika pendaftar tidak memenuhi syarat.

Anda BELUM memenuhi syarat. Minimal nilai matakuliah adalah B dan IPK 2.75 .

Gambar 5. Hasil pengecekan awal dengan web service

Proses seleksi awal untuk mengecek nilai mata kuliah dan IPK minimum dilakukan dengan Web Service. Sistem SPK ini mengirimkan parameter NIM dan kode mata kuliah yang didaftarkan ke SIASAT. Gambar 6 merupakan isi file JSON yang dikirimkan oleh SIASAT yang berisi hasil pengecekan nilai mata kuliah dan IPK minimum.

\{ "nim" : "672017022",

"nilaimk":"tidak memenuhi", "ipk": "tidak menenuhi" \}

Gambar 6. Hasil JSON dari SIASAT

Tabel 1. Data simulasi perhitungan

\begin{tabular}{|c|c|c|c|c|c|c|}
\hline \multirow{2}{*}{ Parameter } & \multicolumn{5}{|c|}{ Alternatif } & \multirow{2}{*}{$\begin{array}{c}\text { Kriteria } \\
\text { Pengambil } \\
\text { Keputusan }\end{array}$} \\
\hline & A & B & C & D & $\mathbf{E}$ & \\
\hline IPK (P1) & 2.85 & 3.54 & 2.93 & 3.77 & 3.26 & Cukup \\
\hline $\begin{array}{l}\text { Nilai Mata } \\
\text { kuliah (Angka) } \\
\text { (P2) }\end{array}$ & 3.50 & 3.00 & 3.50 & 3.00 & 4.00 & Cukup \\
\hline $\begin{array}{l}\text { Nilai Tes }(0- \\
100)(\mathrm{P} 3)\end{array}$ & 85 & 75 & 65 & 70 & 90 & Cukup \\
\hline $\begin{array}{l}\text { Jumlah } \\
\text { Pengalaman } \\
\text { (P4) }\end{array}$ & 1 & 3 & 2 & 1 & 2 & Sekitar 2 \\
\hline $\begin{array}{l}\text { Jumlah Daftar } \\
\text { Mata kuliah } \\
\text { (P5) }\end{array}$ & 3 & 2 & 1 & 4 & 2 & Sekitar 3 \\
\hline
\end{tabular}

Jika memenuhi syarat minimum, maka pendaftar akan disimpan dalam daftar calon asisten dosen untuk selanjutnya diproses lebih lanjut dengan metode TOPSIS dan Profile Macthing. Pembahasan perhitungan ini membutuhkan data simulasi yang disesuaikan agar 
mendekati kasus nyata. Data-data yang akan disimulasikan untuk perhitungan dengan TOPSIS dan Profile Matching dapat dilihat pada Tabel 1.

Pada Tabel 1, terdapat 5 alternatif mahasiswa pendaftar, yaitu Mahasiswa A, B, C, D, dan E. Sedangkan parameter atau kriteria yang ditetapkan adalah IPK, nilai mata kuliah (diubah ke nilai angka: $A=4.0 ; A B=3.5$; $\mathrm{B}=3.0 ; \mathrm{BC}=2.5 ; \mathrm{C}=2.0 ; \mathrm{CD}=1.5 ; \mathrm{D}=1.0 ; \mathrm{E}=0.0$ ), nilai tes, jumlah pengalaman asisten dosen sebelumnya, jumlah mata kuliah yang didaftarkan untuk menjadi asisten dosen. Pada perhitungan ini, pengambil keputusan memberikan kriteria penilaian untuk IPK, nilai mata kuliah dan nilai tes masing-masing adalah cukup. Sedangkan untuk kriteria jumlah pengalaman ditetapkan sekitar 2 dan jumlah mata kuliah yang didaftarkan untuk menjadi asisten dosen adalah sekitar 3. Untuk bobot (w) yang ditetapkan pengambil keputusan masing-masing adalah sebesar 0.20 , $0.25,0.30,0.10,0.15$.

Langkah pertama digunakan metode Profile Matching untuk parameter jumlah pengalaman dan jumlah mata kuliah yang didaftarkan, karena kedua parameter ini harus disesuaikan dengan variabel prediktor ideal yang harus dipenuhi oleh subjek (alternatif), bukan ditentukan berdasarkan maksimum (benefit) maupun minimum (cost) [10]. Proses ini ditunjukkan pada Tabel 2.

Tabel 2 Proses profile matching

\begin{tabular}{cccccc}
\hline \multirow{2}{*}{ Alternatif } & \multicolumn{5}{c}{ Parameter } \\
\cline { 2 - 6 } & P1 & P2 & P3 & P4 & P5 \\
\cline { 2 - 6 } & Benefit & Benefit & Benefit & Sekitar 2 & Sekitar 3 \\
\hline A & 2.85 & 3.50 & 85 & 1 & 3 \\
B & 3.54 & 3.00 & 75 & 3 & 2 \\
C & 2.93 & 3.50 & 65 & 2 & 1 \\
D & 3.77 & 3.00 & 70 & 1 & 4 \\
E & 3.26 & 4.00 & 90 & 2 & 2 \\
\hline
\end{tabular}

Langkah berikutnya adalah menentukan matriks ternormalisasi dengan Rumus 1.

$\mathrm{r}_{\mathrm{ij}}=\frac{x_{i j}}{\sqrt{\sum_{i=1}^{m} x_{i j}^{2}}}$

Sehingga diperoleh matriks ternormalisasi $\mathrm{R}$ sebagai berikut:

$R=\left[\begin{array}{lllll}0.388 & 0.458 & 0.490 & 0.209 & 0.457 \\ 0.481 & 0.392 & 0.432 & 0.626 & 0.305 \\ 0.398 & 0.458 & 0.375 & 0.417 & 0.152 \\ 0.513 & 0.392 & 0.404 & 0.209 & 0.610 \\ 0.443 & 0.523 & 0.519 & 0.417 & 0.305\end{array}\right]$

Matriks keputusan yang ternormalisasi terbobot kemudian dihitung dengan Rumus 2.

$y_{i j}=w_{i} r_{i j}$
Sehingga diperoleh matriks Y ternormalisasi terbobot sebagai berikut:

$Y=\left[\begin{array}{lllll}0.078 & 0.114 & 0.147 & 0.021 & 0.069 \\ 0.096 & 0.098 & 0.130 & 0.063 & 0.046 \\ 0.080 & 0.114 & 0.112 & 0.042 & 0.023 \\ 0.103 & 0.098 & 0.121 & 0.021 & 0.091 \\ 0.089 & 0.131 & 0.156 & 0.042 & 0.046\end{array}\right]$

Solusi ideal positif A+ dan solusi ideal negatif Aditunjukkan pada Tabel 3.

Tabel 3. Solusi ideal positif $\mathbf{A}^{+}$dan negatif $\mathbf{A}^{-}$

\begin{tabular}{lccccc}
\hline $\begin{array}{l}\text { Solusi Ideal } \\
\text { Positif } \mathbf{A}^{+}\end{array}$ & 0.103 & 0.131 & 0.156 & 0.042 & 0.069 \\
\hline $\begin{array}{l}\text { Solusi Ideal } \\
\text { Negatif A }\end{array}$ & 0.078 & 0.098 & 0.112 & 0.021 & 0.046 \\
\hline & & & & 0.063 & 0.091 \\
\hline
\end{tabular}

Solusi ideal positif $\mathrm{A}^{+}$dan negatif $\mathrm{A}^{-}$pada Tabel 3 ditentukan berdasarkan parameter maksimum (benefit), yaitu untuk parameter P1, P2 dan P3. Sedangkan P4 dan P5 ditentukan berdasarkan jarak depan dan belakang dengan prediktor ideal yang harus dipenuhi pada P4 yaitu sekitar

2 dan P5 sekitar 3. Sehingga solusi ideal positif $\mathrm{A}^{+}$untuk P4 adalah: $\frac{2}{\sqrt{\sum_{i=1}^{m} x_{i j}^{2} \cdot w_{i}}}$ dan solusi ideal positif untuk P5 adalah: $\frac{3}{\sqrt{\sum_{i=1}^{m} x_{i j}^{2}} \cdot w_{i}}$. Solusi ideal negatif $\mathrm{A}^{-}$untuk P4 adalah: $\frac{1}{\sqrt{\sum_{i=1}^{m} x_{i j}^{2}} \cdot w_{i}}$ dan solusi ideal negatif untuk P5 adalah $\frac{2}{\sqrt{\sum_{i=1}^{m} x_{i j}^{2} \cdot w_{i}}}$. Nilai 0.063 dan 0.091 masingmasing didapatkan dari perhitungan $\frac{3}{\sqrt{\sum_{i=1}^{m} x_{i j}^{2}} \cdot w_{i}}$ dan $\frac{4}{\sqrt{\sum_{i=1}^{m} x_{i j}^{2}}, w_{i}}$. Kedua nilai ini akan digunakan pada perhitungan $\mathrm{D}^{+}$dan $\mathrm{D}^{-}$di tahap berikutnya.

Jarak antara alternatif dengan solusi ideal positif dihitung dengan Rumus 3.

$D_{i}^{+}=\sqrt{\sum_{j=1}^{n}\left(y_{i j}-y_{i}^{+}\right)}$

Jarak antara alternatif dengan solusi ideal negatif dihitung dengan Rumus 4.

$D_{i}^{-}=\sqrt{\sum_{j=1}^{n}\left(y_{i j}-y_{i}^{-}\right)}$

Sehingga didapatkan hasil seperti pada Tabel 4 dan Tabel 5. 
Tabel 4. Hasil perhitungan $\mathrm{D}^{+}$

\begin{tabular}{ccc}
\hline Alternatif & $\mathbf{D}^{+}$ & $\begin{array}{c}\text { Hasil } \\
\text { Rangking }\end{array}$ \\
\hline A & 0.03745 & 2 \\
B & 0.05233 & 3 \\
C & 0.06894 & 5 \\
D & 0.05678 & 4 \\
E & 0.02675 & 1 \\
\hline
\end{tabular}

Tabel 5. Hasil perhitungan $\mathrm{D}^{-}$

\begin{tabular}{ccc}
\hline Alternatif & $\mathbf{D}^{-}$ & $\begin{array}{c}\text { Hasil } \\
\text { Rangking }\end{array}$ \\
\hline A & 0.04458 & 2 \\
B & 0.02552 & 5 \\
C & 0.03507 & 3 \\
D & 0.02647 & 4 \\
E & 0.05914 & 1 \\
\hline
\end{tabular}

Karena hasil urutan rangking pada Tabel 4 dan Tabel 5 tidak sama, maka dilanjutkan ke perhitungan $\mathrm{C}+$ dan C- masing-masing dengan Rumus 5 dan 6.

$$
\begin{aligned}
& C^{+}=\frac{D_{i}^{+}}{D_{i}^{+}+D_{i}^{-}} \\
& C^{-}=\frac{D_{i}^{-}}{D_{i}^{+}+D_{i}^{-}}
\end{aligned}
$$

Sehingga didapatkan hasil pada Tabel 6.

Tabel 6. Hasil perhitungan $\mathrm{C}^{+}$dan $\mathrm{C}^{-}$

\begin{tabular}{ccccc}
\hline Alternatif & Hasil C $^{+}$ & $\begin{array}{c}\text { Rangking } \\
\text { C }^{+}\end{array}$ & Hasil C & $\begin{array}{c}\text { Rangking } \\
\text { C }^{-}\end{array}$ \\
\hline A & 0.45656 & 2 & 0.54344 & 2 \\
B & 0.67219 & 4 & 0.32781 & 4 \\
C & 0.66282 & 3 & 0.33718 & 3 \\
D & 0.68199 & 5 & 0.31801 & 5 \\
E & 0.31145 & 1 & 0.68855 & 1 \\
\hline
\end{tabular}

Berdasarkan hasil pada Tabel 6, maka hasil perangkingan dari urutan terbaik adalah Mahasiswa E, Mahasiswa A, Mahasiswa C, Mahasiswa B, dan Mahasiswa D. hasil ini dapat dijadikan acuan dalam proses seleksi dan penerimaan asisten dosen di FTI UKSW supaya hasilnya sesuai dengan keinginan pengambil keputusan, yaitu dosen koordinator mata kuliah. Gambar 7 merupakan tampilan pada aplikasi untuk hasil proses seleksi pada SPK.

Hasil Seleksi Asisten Dosen (PEMROGRAMAN - IN123 - Semester Genap 2018/2019)
\begin{tabular}{|l|c|c|c|c|}
\hline No. & NIM & NAMA MAHASISWA & URUTAN RANGKING & AKSI \\
\hline 1 & 672016014 & Jeremy Alexander Widjaya & 1 & LIHAT DETAIL \\
\hline 2 & 672015115 & Debby Andrea Dewi & 2 & LIHAT DETAIL \\
\hline 3 & 672015089 & Panji Setiawan Aji & 3 & LIHAT DETAIL \\
\hline 4 & 672016321 & Doddy Eka Saputra & 4 & LIHAT DETAIL \\
\hline 5 & 672015025 & Michael Andrew Jatmiko & 5 & LIHAT DETAIL \\
\hline
\end{tabular}

\section{Gambar 7. Tampilan pada aplikasi SPK untuk hasil} seleksi asisten dosen

Pengujian aplikasi SPK dilakukan dengan pengujian Black Box Testing, di mana pengujian ini dilakukan oleh developer untuk memastikan semua fungsi dalam aplikasi sudah berjalan dengan baik [15]. Pengujian dilakukan terutama pada proses pengecekan awal nilai mata kuliah dan IPK minimum melalui Web Service. Berdasarkan pengujian pada proses tersebut, sistem dapat berjalan sesuai yang diharapkan. Untuk pengujian Black Box berikutnya dilakukan pada proses seleksi menggunakan metode TOPSIS dan Profile Macthing, di mana telah dilakukan 10 kali proses seleksi asisten dosen pada sistem dan dicocokkan dengan perhitungan manualnya. Hasil menunjukkan bahwa hasil perhitungan pada sistem sudah sesuai dengan perhitungan manualnya.

\section{Kesimpulan}

Berdasarkan penelitian yang sudah dilakukan, maka dapat disimpulkan bahwa perancangan SPK pemilihan asisten dosen dapat dimodelkan dengan metode TOPSIS dan Profile Matching dengan teknologi Web Service. Profile Matching berguna untuk menangani parameter yang bukan didasarkan pada nilai maksimum (benefit) dan minimum ( cost), tetapi berupa nilai ideal yang harus dipenuhi sesuai dengan persyaratan pengambil keputusan. Hasil dari Profile Matching kemudian dikombinasikan dengan metode TOPSIS untuk mendapatkan keluaran berupa rangking. Teknologi Web Service berguna untuk menyaring parameter IPK dan nilai mata kuliah minimum yang didapatkan dari transkrip nilai mahasiswa di database SIASAT. Hasil seleksi akhir pada sistem juga sesuai dengan hasil perhitungan manual. Hasil seleksi ini dapat digunakan untuk membantu dosen koordinator mata kuliah dalam proses penyeleksian asisten dosen. Saran yang bisa dikerjakan selanjutnya adalah dengan menyediakan fasilitas tes online untuk kepentingan seleksi asisten dosen, sehingga semua proses terintegrasi dalam satu sistem.

\section{Daftar Pustaka}

[1] S. Diputra, I. G. D. Susila, I. A. Wijaya dan I. N. Yudi, "Penentuan Minat Asisten Dosen dengan Metode SAW Berbasis Web (Studi Kasus: STIKOM Bali)," JOSIKOM: Jurnal Online Sistem Komputer, vol 1, no. 1, 2015 [Online]. Available: http:// id.portalgaruda.org/?ref=browse\&mod=viewarticle\&article $=395699$. [Accessed: 20-Sep-2017].

[2] I. M. D. Susila, "Analisa dan Perancangan Sistem Pendaftaran dan Ujian Seleksi Asdos (Asisten Dosen) STMIK STIKOM Bali," Jurnal Sistem dan Informatika, vol. 10, no. 2, pp. 67-76, 2016 [Online]. Available: http://jsi.stikom-bali.ac.id/index.php/ jsi/article/view/59. [Accessed: 05-Sep-2017].

[3] S. B. Aji, "Sistem Pendukung Keputusan Seleksi Asisten Laboratorium Dosen Elektro menggunakan Metode Weighted Product di Polines," Skripsi, Teknik Informatika Fakultas Ilmu Komputer Universitas Dian Nuswantoro, Semarang, Indonesia, 2015.

[4] M. A. Budhi dan R. Wardoyo, “ Group Decision Support System Determination Of Best Employee Using Topsis And Borda," IJCCS (Indonesian J. Comput. Cybern. Syst.), vol. 11, no. 2, pp. 165-176, 2017 [Online]. Available: https://jurnal.ugm. ac.id/ijccs/article/view/22773. [Accessed: 05- 
Sep-2017]

[5] N. Ilham dan S. Mulyana, "Sistem Pendukung Keputusan Kelompok Pemilihan Tempat PKL Mahasiswa dengan Menggunakan Metode AHP dan Borda," IJCCS Indonesian J. Comput. Cybern. Syst.), vol. 11, no. 1, pp. 55-66, 2017 [Online]. Available: https://jurnal.ugm.ac.id/ijccs/article/ view/16595. [Accessed: 05-Sep-2017].

[6] M. Mladineo, N. Mladineo and N. Jajac, "Project Management in mine actions using multi-criteriaanalysis-based decision support system," Croatian Operationa; Research Review, vol. 5, pp. 415-425, 2014.

[7] P. Lacroix, H. Santiago and N. Ray, "MASCOT: Multi-Criteria Analytical SCOring Tool for ArcGIS Desktop," International Journal of Information Technology \& Decision Making, vol. 13, pp. 1135-1159, 2014.

[8] M. Mladineo, N. Jajac and K. Rogulj, "A Simplified Approach to the PROMETHEE Method for Priority Setting in Management of Mine Action Projects," Croatian Operational Research Review (CRORR), pp. 249-268, 2016 [Online]. Available: http://hrcak.srce.hr/ojs/index.php/crorr/ article/view/4534.

[9] C., Yeh. 2002, "A Problem-based Selection of Multi-Attribute Decision Making Methods," International transaction in Operational Research, pp. 169-181, Blackwell Publishing.

[10] A. Suhartanto, Kusrini, and Henderi, "Decision Support System untuk Penilaian Kinerja Guru dengan Metode Profile Matching," Jurnal Komputer Terapan, vol. 2, no. 2, pp. 149-158, 2016 [Online].
Available: https://media.neliti.com/media/ publications / 169344-ID-decision-supportsystem-untuk-penilaian.pdf. [Accessed: 24-Dec2018].

[11] F. N. Allokendek, J. Soetikno, and A. Ashari, "Integrasi Database DISDUKCAPIL dan Database KPU Kabupaten Maros Memanfaatkan Web Services, "IJCCS (Indonesian J. Comput. Cybern. Syst.), vol. 7, no. 1, pp. 1-12, 2013 [Online]. Available: https://jurnal.ugm.ac.id/ijccs/article/ view/3047. [Accessed: 05-Sep-2017].

[12] Y. D. Salman and N. L. Hashim, "Test Case Generation Model for UML Diagrams," Journal of Telecommunication, Electronic and Computer Engineering, vol 9, no. 2-2, pp. 171-175, 2017 [Online]. Available: http://journal.utem.edu. my/index.php/jtec/article/viewFile/2239/1357. [Accessed: 20-Sep-2017].

[13] B. Bonilla-Morales, S. Crespo and C. Clinie, "Reuse of Use Cases Diagrams: An Approach based on Ontologies and Semantic Web Technologies," IJCSI International Journal of Computer Science, vol. 9, no. 2, pp. 24-29, 2012.

[14] A. Al-Shamailh, "An Experimental Comparison of ER and UML Class Diagram," International Journal of Hybrid Information Technology, vol. 8, no. 2, pp. 279-288, 2015.

[15] M. S. Mustaqbal, R. F. Firdaus and H. Rahmadi, "Pengujian Aplikasi Menggunakan Black Box Testing Boundary Value Analysis," Jurnal Ilmiah Teknologi Informasi Terapan (JITTER), vol. 1, no. 3, pp. 31-36, 2015 [Online]. Available: http:// jitter.widyatama.ac.id/index.php/jitter/article/ view/70. [Accessed: 05-Sep-2017]. 